\title{
Escobar, Arturo (2020), Pluriversal Politics: The Real and the Possible
}

Fronika de Wit

\section{(2) OpenEdition \\ Journals}

Electronic version

URL: https://journals.openedition.org/rccs/12507

DOI: $10.4000 /$ rccs. 12507

ISSN: 2182-7435

Publisher

Centro de Estudos Sociais da Universidade de Coimbra

\section{Printed version}

Date of publication: 1 December 2021

Number of pages: 153-156

ISSN: 0254-1106

\section{Electronic reference}

Fronika de Wit, "Escobar, Arturo (2020), Pluriversal Politics: The Real and the Possible", Revista Crítica de Ciências Sociais [Online], 126 | 2021, Online since 27 January 2022, connection on 29 January 2022. URL: http://journals.openedition.org/rccs/12507 ; DOI: https://doi.org/10.4000/rccs. 12507 
$\mathrm{Na}$ sequência do capítulo 5, salientamos algumas considerações. Em relação aos grupos de WhatsApp, é necessário pensar, a despeito da sua óbvia importância, o quão dependente se pode ficar de tecnologias que fazem parte desse ecossistema de plataforma e o quão vulneráveis estão essas comunicações nessas redes. Por exemplo, pode-se refletir acerca da dificuldade de acesso à internet em algumas situações, como no caso de trabalhadores que têm um plano de dados limitado e que não conseguem se manter conectados constantemente. Sobre a propensão dos trabalhadores a fazerem greve, podem existir algumas dificuldades, como potenciais represálias para quem participou nas mesmas, seja por exemplo a redução no número de demandas ou o bloqueio injustificado.
O livro é um importante contributo no entendimento da nova forma de organização coletiva dos trabalhadores de plataforma. Revela-se uma alternativa essencial à grande ênfase que é dada aos estudos das novas formas de gerenciamento algorítmico e ao uso das tecnologias em detrimento do estudo a partir dos próprios trabalhadores e como estes se relacionam com essas novas condições de trabalho. A utilização dos métodos do operaísmo italiano revelam-se ferramentas importantes nesse objetivo. Trata-se, portanto, de uma leitura oportuna na constituição de um arcabouço que coloque o trabalhador como centro das discussões da nova morfologia do mundo do trabalho.

Vinícius Torres Araújo Dourado
Revisto por Alina Timóteo

\section{Vinícius Torres Araújo Dourado}

Ministério Público do Trabalho I Estudante de graduação em Sociologia, Universidade de Brasília SAUN, Quadra 5, Lote C, Torre A, Centro Empresarial CNC, CEP 70.040-250, Brasília-DF, Brasil Contacto: viuaraujo@gmail.com ORCID: https://orcid.org/0000-0001-9932-3130

https://doi.org/10.4000/rccs.12493

\section{Escobar, Arturo (2020), Pluriversal Politics: The Real and the Possible. Durham, N.C.: Duke University Press, 232 pp. Translation by David Frye}

"We must sentipensar (feel-think) new notions about what is real and thus what is possible” (p. 2). Criticizing conventional science and modernist politics, the Colombian-American anthropologist
Arturo Escobar's latest work, Pluriversal Politics: The Real and the Possible, proposes opening up a new perspective on reality and possibility. Published by Duke University Press (DUP) in 2020, 
Pluriversal Politics elaborates on the concept of "the Pluriverse" - "a world where many worlds fit" (p. 9) - and emphasizes the World Social Forum slogan that "Another world is possible". Escobar, Distinguished Professor of Anthropology at the University of North Carolina (in the United States), highlights how today's "heteropatriarchal capitalist modern/ /colonial world system" (p. xii) wants us to believe that there are no alternatives. However, in a world facing complex challenges, or, as Escobar puts it, "a civilizational crisis" (p. xxxii), we need alternatives: alternative realities, alternative possibilities, alternative futures.

The pluriverse is a recurrent theme in Escobar's work, which he himself places within the ontological turn in social theory and the emergent analytical framework of political ontology. ${ }^{1}$ His famous 1995 book Encountering Development, in which he deconstructs the concept of development and proposes alternative visions for a post-development era, was republished in 2011 with a new introduction that links post-development to studies of the pluriverse. ${ }^{2}$ Also, in 2018 the DUP published Escobar's Designs for the Pluriverse, ${ }^{3}$ in which the author focuses on the ontological dimension of design for sustainability and urges for "autonomous design". Designs for the Pluriverse summarizes emerging pluriversal movements, from both Europe and Latin America, such as degrowth, transition initiatives, Buen Vivir and the rights of nature.

Pluriversal Politics is the English translation of the book Otro posible es posible: caminando bacia las transiciones desde Abya Yala/Afro/Latino-América ${ }^{4}$ that was published in Colombia in 2018 by Ediciones Desde Abajo. At that time, Escobar thought that writing in Spanish was more urgent, but, as he stated in the 2020 book's acknowledgements: "I knew very well that what doesn't exist in English doesn't exist for the Anglo-American academy" (p. xl). That is why he decided to provide an English translation later on. However, contrastingly to the Spanish-written version, the English edition contains a preface of about 35 pages which provides the English readers with a profound Latin American context and the continent's tensions between modernist and ontological politics.

As Escobar explains in the book's preface, modernist politics, on the one hand, heavily rely on ontological dualisms, such as the nature/culture, object/subject, fact/value and reason/emotion divide. Ontological or pluralistic politics, on the other hand, draw on the concept of radical relationality: "all entities that make up the world are so deeply interrelated that they have no intrinsic, separate existence by themselves" (p. xiii). But can modernist politics, and especially leftist

\footnotetext{
${ }^{1}$ See: de la Cadena, Marisol; Blaser, Mario (eds.) (2018), A World of Many Worlds. Durham, N.C.: Duke University Press; and Blaser, Mario (2009), "Political Ontology", Cultural Studies, 23(5-6), 873-896.

${ }^{2}$ Escobar, Arturo (2011), Encountering Development. The Making and Unmaking of the Third World. Princeton: Princeton University Press [orig. ed. 1995].

${ }^{3}$ Escobar, Arturo (2018), Designs for the Pluriverse: Radical Interdependence, Autonomy, and the Making of Worlds. Durham, N.C.: Duke University Press.

${ }^{4}$ Which roughly translates to "Another possible is possible: towards the transitions from Abya Yala/Afro/Latin America”.
} 
politics, contribute to pluriversal politics and lead to a pachakuti, a world reversal? According to Escobar, they may do so, but he emphasizes that struggles related to autonomy, territory and communality "require an explicit ontological framing that advances the principles of interdependence and relationality" (p. xix).

Pluriversal Politics aims to inspire its readers and to open their mind ontologically. To do so, it presents eight essays, or actually ensayos: a Latin-American style of writing that reflects the continent's current intellectual-political debates. The essays are stand-alone texts, but taken together they aim to build toward the understanding that a pluriverse world is possible. To move beyond our modern ontological and epistemic formation, the ensayos present tools for rethinking reality and possibility, from both non-academic and academic sources.

Chapter 1 is the most theoretically dense and presents insights from ancestral sources, such as indigenous cosmovisions and Buddhism, and theoretical sources, such as cybernetics and the ontological turn in social theory. The next two ensayos, Chapters 2 and 3, are more focused on relational ontologies of territory-peoples, such as the indigenous Nasa people living in the southwestern highlands of Colombia, who proclaim the possibility of another world to come: "the Liberation of Mother Earth". The following chapters touch upon parts of social and critical theory: the ontological dimension of the Epistemologies of the South (Chapter 4), emerging Latin American Social Theory, such as Buen Vivir, the rights of nature and decolonial feminism (Chapter 5), and the rearticulation of the concept of Postdevelopment (Chapter 6). Finally, the book explores pluriversal politics in practice, and the potential of true codesign strategies with a genuine intercultural dialogue for a transition towards sustainability of life as a whole (Chapters 7 and 8 ). Especially for readers who are new to Escobar's work, Pluriversal Politics can be a very inspiring and enlightening read. I say "can be" because the book is not suitable for all types of readers: due to its form (ensayos), as also noted by Escobar himself, the reader needs to exercise "epistemic pluralism" in order to truly capture the publication's messages and insights. Also, rationalists will probably judge Escobar for looking at the world through rose-coloured glasses and deem pluriversal politics not to be workable in practice. However, according to Escobar this critique is "of capitalocentric and globalocentric nature" and "modernist and masculinist political thinking" (p. xx). As he states, "aren't the true romantics the people who insist that more of the same (more corporate solutions, more World Bank-style development, more 'green economies') will lead to lasting improvements?” (p. 6).

If you are looking for a book that scrutinizes the theoretical aspects of the pluriverse and pluriversal politics, you might prefer Escobar's Designs for the Pluriverse, which is written in a more "academic" style when it comes to argumentation and conclusion. However, Pluriversal Politics, which does not contain a conclusion, offers a refreshing combination of activism and emerging Latin American social theory. It provides a platform for territorial-based indigenous peoples perspectives, confronted with large-scale extractive development projects. Also, all ensayos open with inspiring quotes, poems and lyrics, and Chapter 8 even proposes a short meditation exercise. This creative style helps the mind to open to new possibilities and sentipensar: a way of thinking that does not separate reason from emotion nor knowledge from caring. 
All in all, Pluriversal Politics is a must-read for anyone willing to step out of their onto-epistemic comfort zone. It makes you reflect on ontologies of separation that we, often unconsciously, carry within us and provides hope for the future. Because, like Escobar says, "we may be witnessing the slow rebirth of the pluriverse" (p. 12).

Fronika de Wit

Edited by Alina Timóteo

\section{Fronika de Wit}

PhD Student at Instituto de Ciências Sociais, Universidade de Lisboa

Av. Prof. Aníbal de Bettencourt, 9, 1600-189 Lisboa, Portugal

Contacto: fronika.wit@ics.ulisboa.pt

ORCID: https://orcid.org/0000-0002-6181-3537

https://doi.org/10.4000/rccs. 12507

\section{Tamayo, Juan José (2020), La Internacional del odio ¿Cómo se construye? ¿Cómo se deconstruye? Barcelona: Icaria, 223 pp.}

La Internacional del odio es el título del último y bien acogido libro de Juan José Tamayo, doctor en teología y filosofía con una dilatada trayectoria como profesor y conferenciante en universidades europeas, latinoamericanas, africanas y norteamericanas. Con más de 70 libros publicados sobre, entre otros temas, ciencias de la religión, fundamentalismo religioso, diálogo intercultural e interreligioso, laicidad, feminismo, teología decolonial y teología de la liberación, Tamayo es secretario general de la Asociación de Teólogos y Teólogas Juan XxIII y miembro del Comité Internacional del Foro Mundial de Teología y Liberación.

Como el propio autor explica, el germen del libro fue el curso de doctorado "Epistemologías y teologías del Sur: decolonialidad y prácticas emancipatorias", impartido en Curitiba (Brasil) en 2019 por invitación de la Pontificia Universidad Católica de Paraná. En ese momento, Jair Bolsonaro, con el apoyo de importantes sectores evangélicos, ejercía la presidencia del país. Tamayo rescata y extrapola al contexto brasileño el término "cristofascismo”, acuñado en 1970 por la teóloga Dorothee Sölle respecto a las relaciones entre el Partido Nazi y las iglesias cristianas durante la formación del Tercer Reich, para referirse, a partir de una definición más amplia y actualizada del concepto, a la nueva alianza entre iglesias fundamentalistas evangélicas, grupos católicos integristas y la extrema derecha a fin de implantar en Brasil un gobierno de corte autoritario con características neofascistas y neoliberales.

No obstante, Tamayo va más allá del contexto brasileño para defender, de manera ampliamente documentada y sólidamente 